\title{
CUIDAR DO SER E DA PALAVRA: PRÁTICAS DE LEITURA NAS AÇÕES PEDAGÓGICAS DA “CASA DOS SONHOS” EM SANTA RITA/ PB
}

\author{
Nelma Rejane Olinto de Oliveira Pereira \\ Orientanda
}

\author{
Prof. ${ }^{a}$ Doutora Edna Gomes Pinheiro \\ Orientadora - DCI/UFPB
}

\section{Resumo}

Parte dos pressupostos de que a leitura é o caminho mais lógico para articular saberes que se encontram desarticulado na relação imprescindível entre o leitor, o livro e a cidadania considerando o seu potencial de criar elos de reencontro, que orientado por uma perspectiva transformadora faz do ato de ler, uma forma de criar e expressar visões de mundo, segundo os desejos e aspirações dos envolvidos no processo de construção do conhecimento. Aponta como problema a seguinte questão: como as práticas de leituras desenvolvidas, na Casa dos Sonhos, contribuem para a construção da história de vida da comunidade assistida por essa instituição? Tem como objetivo geral: analisar as práticas de leitura das ações pedagógicas na "Casa dos Sonhos" em Santa Rita / Paraíba no período de 2010 - 2015. E, como objetivos específicos: analisar as práticas educacionais promovidas pela Associação Casa dos Sonhos e sua repercussão na vida da comunidade; delinear as ações desenvolvidas, pelos mediadores da leitura, na Casa dos Sonhos; analisar a importância da leitura nas práticas dos educadores em diálogo com os educadores. Mesclam, no percurso metodológico, técnicas advindas da abordagem qualitativa, e da prática da história oral. Utiliza como técnicas de coleta dos dados - a entrevista e o diário de campo. Salienta que os sujeitos da pesquisa estão definidos por um grupo de quatro (04) educadoras, selecionado intencionalmente, apesar de termos considerado, a experiência e a vivência na instituição pesquisada, idade e disponibilidade. Ao analisarmos a Associação Casa dos Sonhos e as ações pedagógicas presentes, percebemos que a instituição tem desenvolvido um projeto educacional que alia a capacidade criativa e o dinamismo da educação popular em seu cotidiano. Concluímos que as práticas sociais desenvolvidas na Casa dos Sonhos, a libertação, a emancipação e a experiência de cuidar, são realidades palpáveis. Elas estão presentes diante do ato de cuidar e das práticas de leitura advindas dos educadores-mediadores, que participam do cotidiano da associação, nesse sentido o cuidar se estabelece.

Palavras-chave: Biblioteca escolar. Leitura. Práticas de leitura. 